\title{
Peran Santri Terhadap Kemajuan Filsafat Pendidikan Islam
}

Idris Sodiq

Universitas Muhammadiyah Jember

Email : Idrissodiq08031997@gmail.com..

Hairul Huda

Universitas Muhammadiyah Jember

Email : hairulhuda@unmuhjember.ac.id

Nida' Fajri Anjas Ikawati

Universitas Muhammadiyah Jember

Email : nidafai2000@gmail.com

\section{Submission}

\section{ABSTRACT}

\section{Track:}

Received:

6 Agustud 2020

Final Revision:

1 Sepetember 2020

Available online:

25 September 2020

Corresponding

Author:

Name \& E-mail Address

Idris Sodiq

Idrissodiq08031997@gmail.com..

Hairul Huda

In the philosophy of Islamic education, students act as one of the determinants of concepts or theories in Islamic education. This is caused by the role of students who jump into the community in order to practice the knowledge that has been obtained from pesantren, or what is often referred to as devotion. So that students also know a lot of things that are lacking in the midst of social life, and students are required to correct the shortcomings of the community. So from this either realize or not realize the students make a very large contribution to the philosophy of Islamic education, where the philosophy of Islamic education is a forerunner or theoretical concept of various Islamic education.

Keywords : students, philosophy of Islamic Education

hairulhuda@unmuhiember.ac.id

Nida' Fajri Anjas Ikawati

nidafai2000@gmail.com 


\section{PENDAHULUAN}

Pada hakikatnya filsafat pendidikan islam adalah sebuah bahasan yang menarik untuk di bahas, yang mana ini di karenakan filsafat pendidikan islam itu sendiri bisa di lihat dari banyak sudut pandang, hal ini berdasar dari pengertian kata filsafat yang merupakan pemikiran yang berasal dari rasionalitas maupun empiris, yang mana dari berbagai sudut pandang tersebut mempunyai tipologi tersendiri. Akan tetapi setelah filsafat itu di hubungkan dengan pendidikan Islam, maka dari situlah filsafat (pemikiran) di padukan dengan ajaran-ajaran yang di dalamnya terkandung nilai-nilai keislaman, sehingga apabila ada yang tidak sesuai dengan nilai-nilai ajaran Islam, maka pemikiran filsafat tersebut tidak di pakai dalam pendidikan islam.

Dari berbagai sudut pandang itu salah satunya yang pertama berasal dari sumber pemikiran, yaitu artinya sumber pemikirannya tidak hanya berasal dari sumber ajaran murni dari dalam Al-qur'an, Assunnah, serta dari berbagai pendapat para alim ulama. Tetapi salah satunya berasal dari falsafah Bangsa dan Negara serta dari tuntutan modernitas yang di hadapi. Yang kedua berasal dari dasar pemikiran, yaitu dasar pemikirannya tidak hanya dari filsafat Islam, Akan tetapi kemungkinan besar juga dari pemikiran-pemikiran filsafat orang yunani atau pemikiran filsafat orang barat yang pada akhirnya di saring dan di pilih sesuai yang tidak bertentangan dengan ajaran Islam. Yang ketiga bisa berasal dari wacana pemikiran yang berkembang yang berhubungan dengan aktifitas pendidikan Islam itu sendiri, yang biasanya mencakup kepada tujuan pendidikan, kepada pendidik dan peserta didik, kurikulum serta kepada metode yang tepat dengan keadaan lingkungannya. Dengan kata lain wacana ini bisa bersifat universal yang bisa di aplikasikan di berbagai tempat sesuai dengan keadaan perkembangan zaman, dan bisa juga bersifat khusus pada keadaan tempat di satu zaman tertentu saja. Bahkan bisa jadi masih banyak berbagai sudut pandang lain yang belum kami temukan (Tolchah, 2015).

Dari sedikit latar belakang filsafat pendidikan Islam tersebut, maka seolah-olah hal ini menarik eratannya dengan seorang santri, yang mana notaben seorang santri di kenal sebagai orang yang menuntut ilmu agama, dan sudah jelas ilmu agama berasal dari ajaran Islam. Maka dari itu lewat tulisan ini penulis berusaha mencoba menelusuri keterkaitan antara santri dengan filsafat pendidikan Islam itu sendiri.

\section{METODE}

Metode penelitian pada dasarnya merupakan cara untuk mendapatkan data yang valid untuk memahami suatu permasalahan dan akan dipertanggung jawabkan sebagaimana mestinya. Pendekatan dalam penelitian ini menggunakan penelitian kualitatif. Menurut Saryono (2010) penelitian kualitatif adalah penelitian yang tidak dapat dijabarkan dengan penelitian kuantitatif. Menurutnya penelitian ini merupakan gambaran, penjabaran atau deskripsi dari sebuah keadaan social. Menurut Sugiyono (2011) mengatakan bahwa metode penelitian kualitatif adalah metode berdasarkan filsafat post positivism, digunakan meneliti obyek 
alamiah dimana peneliti sebagai instrument kunci, dengan teknik pengumpulan data menggunakan cara triangulasi (gabungan). Analisis data bersifat induktif atau kualitaitf, hasil penelitian menekankan arti atau makna daripada generalisasi.

Dalam penelitian ini menggunakan penelitian pustaka atau Library Research yaitu pengumpulan data dari berabagai sumber yang terdapat di perpustakaan seperti buku, dokumen dan catatan - catatan. Data yang diperoleh nantinya akan menjadi landasan untuk pelaksanaan lapangan (Zed, 2008). Menurut (Sarwono, 2006) studi pustaka adalah mempelajari buku referensi dan hasil penelitian sebelumnya yang sejenis untuk mendapatkan landasan teori mengenai masalah yang akan diteliti. Data penelitian berasal dari berbagai sumber yaitu sumber primer dan sekunder. Data primer merupakan sumber data yang langsung didapat dari responden (Sugiyono, 2015). Sedangkan data sekunder adalah sumber data yang didapat secara tidak langsung dari responden, misal melalui orang lain atau melalui dokumen (Sugiyono, 2015).

Dalam penelitian ini uji keabsahan data menggunakan uji kreadibilitas data yang dilakukan dengan perpanjangan pengamatan, meningkatkan ketekunan, triangulasi, diskusi dengan teman sekelompok (Sugiyono:2011)

\section{HASIL dan PEMBAHASAN}

\section{Memahami Makna Santri}

Santri pada umumnya bagi masyarakat awam santri di artikan sebagai orang atau murid yang mencari ilmu agama dalam sebuah pesantren, atau santri bisa di katakan juga sebagai orang (peserta didik) yang menuntut ilmu di dalam pesantren. Sedangkan jika kita mengacu pada Kamus Besar Bahasa Indonesia (KBBI) pengertian santri dapat di artikan sebagai (1) orang yang berusaha mendalami agama Islam, (2) orang yang melakukan ibadah secara sungguh-sungguh, (3) orang yang sholeh/sholeha. Maka berhubungan dengan hal ini Mafred Ziemek membagi istilah santri menjadi dua bagian. Yang pertama adalah santri mukim, yang mana santri mukim ini adalah santri yang belajar atau menuntut ilmu yang sekaligus bertempat tinggal di dalam pesantren. Yang kedua adalah santri kalong, santri kalong ini sendiri adalah santri yang sama-sama belajar di lingkungan pesantren namun tidak langsung bertempat tinggal di dalam pesantren, santri ini belajar berangkat dari rumah masing-masing. Besar kecilnya atau tumbuh berkembangnya pesantren biasanya di ukur dari banyaknya santri yang berada dalam pesantren tersebut. Selain kedua istilah santri tersebut, ada istilah lain menurut Arifin dan Sunyoto yaitu : santri alumnus merupakan santri yang telah dinyatakan lulus dan tidak lagi memiliki kewajiban sebagai seorang santri layaknya santri mukim akan tetapi masih berhubungan erat dengan pesantren maupun kyai. Santri luar merupakan santri yang memiliki hubungan erat dengan kyai, mereka datang dalam rangka menghadiri majlis ilmu yang disampaikan oleh kyai seperti kajian. Mereka bukanlah santri mukim maupun santri kalong karena mereka tidak terdafatar secara resmi di dalam pesantren. (Arifin dan Suyoto dalam Arifin, 1993). Dari sini dapat di simpulkan bahwasanya bagi kebanyakan masyarakat, santri erat hubungannya bahkan tak 
bisa lepas dari kata pesantren, lalu bagaimana seharusnya pengertian santri itu pada zaman yang sudah modern dan serba canggih ini? padahal di zaman modern dan serba canggih seperti saat ini orang-orang yang ingin menuntut ilmu agama bisa dari mana saja, bahkan jika santri hanya di simpulkan dan harus berada di dalam sebuah pesantren, besar kemungkinan seorang santri bisa menjadi gaptek, kurang mempunyai pengalaman/pengetahuan dan kurangnya daya saing dengan orang-orang luar.

Namun juga di zaman yang sudah modern ini merupakan tantangan besar bagi santri karena perkembangan arus globalisasi yang sangat pesat. Ketika santri telah keluar dan terjun ke lingkungan masyarakat untuk menyalurkan kontribusinya dalam lingkup pendidikan mereka akan dihadapkan dengan sebuah problem yaitu godaan duniawi akibat dari arus globalisasi tersebut. Disinilah santri harus dapat membentengi dirinya dengan segala ilmu dan pengalaman akan nilai - nilai etika dan moral yang telah mereka dapat dalam pendidikannya di pesantren (Majid, 1997). Kemudian barulah santri yang telah terjun ke masyarakat tersebut dapat mengajarkan segala apa yang mereka pelajari dari pesantren kepada anak didik dilingkungan masyarakat.

Pendidikan yang diterima santri di pesantren memiliki tujuan mengarahkan, membimbing serta mendidik santri untuk menjadi individu yang berakhlak mulia, bertaqwa dan memiliki kemandirian serta menanamkan bahwa kewajiban mereka hanya untuk beribadah kepada Allah SWT. Dalam hal ini maka santri lebih ditekankan pada pengembangan karakter atau watak secara individu sesuai dengan kemampuan yang ada pada dirinya. Sehingga watak yang telah terbentuk dari sebuah proses pendidikan di pesantren akan menajdi modal bagi santri untuk dapat berinteraksi dengan lingkungan dengan baik.

Selanjutnya pada keadaan zaman yang seperti saat ini, santri kerap kali menjadi suatu topik pembicaraan tentang identitasnya, baik personal maupun komunal. Sehingga santri sering mencoba untuk mencari tahu tentang identitasnya dirinya, seperti kalangan santri remaja yang mencari identitas dirinya sendiri di tengah beragam interaksi sosial budaya. dan ada pula yang sudah mengetahui identitas dirinya dan memilih untuk memperkuat identitas dirinya tersebut dengan mencoba membangun identitas kesantriannya dengan kehendaknya, misalnya dengan keinginan menjadi santri pengusaha melalui interaksi bisnis global (Chamidi, 2017).

Dari berbagai asumsi yang sudah di paparkan di atas, maka dapat di ambil kesimpulan bahwa santri merupakan sosok dengan identitas yang jelas ke-Islamannya yang terdidik dengan matang di dalam pesantren yang menjunjung tinggi nilai spiritual dan moral dalam kehidupannya. Pesantren sendiri menjadi lembaga peradaban Islam yang mendidik dan mematangkan santri menjadi sosok yang menjunjung tinggi nilai spiritual dan moral dalam kehidupannya. Identitas santri dan pesantren justru terletak pada misi dan risalah yang khas berperadaban berupa spiritualitas dan moral Islam. Dengan kata lain, siapa saja orang Islam yang menggunakan spiritualitas dan moral Islam dalam kehidupannya, maka ia dapat 
dikategorikan sebagai santri setidaknya disebut hidup ala santri walaupun mungkin saja ia tidak mengenyam matang pendidikan peradaban di pesantren. Dengan segala ilmu dan nilai - nilai moral berlandaskan nilai keislaman yang santri dapat maka santri diharap siap untuk berkontribusi langsung untuk menyalurkan segala ilmu tersebut.

\section{Pemahaman Filsafat Pendidikan Islam}

Pendidikan Islam merupakan salah satu usaha sadar yang di lakukan orang Muslim untuk mengarahkan dan membimbing seseorang ke jalan yang sesuai dengan ajaran Islam. Akan tetapi sebelum mengarahkan dan membimbing seseorang, maka ada hal-hal yang perlu di pahami terlebih dahulu apa saja yang menjadi landasan dari pendidikan islam itu sendiri, sehingga pemahaman tentang pendidikan islam dapat tersampaikan dengan menyeluruh sesuai dengan ajaran islam. Pendidikan Islam sendiri di dasarkan pada beberapa landasan, salah satunya yaitu landasan filosofis. Landasan filosofis ini berasal dari kajian filsafat, yang di dalamnya mempelajari tentang ontology, epistimologi, dan aksiologi. Sehingga pada akhirnya menjadi salah satu landasan pengetahuan pendidikan Islam, dan dapat bermanfaat bagi kita sebagai calon pendidik.

Pertama adalah Ontology. Ontology merupakan suatu bahasan yang di dalamnya membahas tentang hakikat adanya sesuatu. Kata ontology sendiri berasal dari dua kata dasar, yaitu ontos yang artinya ada, dan logos yang berarti ilmu/teori. Maka secara garis besar ontology dapat di artikan sebagai suatu kajian ilmu yang mengkaji tentang hakikat dari segala sesuatu yang ada. Hakikat dalam kajian itu sendiri yaitu untuk mencari keberadaan sebenarnya yang pasti dari suatu hal, bukan hanya mencari keberadaan sesuatu yang hanya sementara. Maka dalam hal pendidikan Islam, ontology ini adalah suatu kajian yang mencari tahu tentang hakikat dari pendidikan Islam dari berbagai pengetahuan yang ada. Salah satunya untuk mencari tahu apa hakikat dan tujuan dari pendidikan islam itu sendiri? Sehingga kemudian dari situlah dapat di temukan hakikat pendidikan islam yang sebenarnya, dan di harapkan mampu memahamkan pendidik maupun peserta didik tentang hakikat keberadaan pendidikan islam.

Kedua adalah epistimologi. Epistimologi merupakan suatu bahasan yang membahas tentang cara mengetahui sumber-sumber pengetahuan tentang sesuatu. Epistimologi sendiri berasal dari dua kata dasar yang mempunyai arti masing-masing, yaitu episteme yang mempunyai arti pengetahuan. Dan logos yang berarti ilmu/teori. Dari pengertian dua kata dasar ini maka epistimologi secara garis besar dapat di artikan sebagai suatu cabang ilmu filsafat yang mempelajari asal mula atau sumber pengetahuan. Di filsafat orang-orang barat terdapat dua sumber pengetahuan yang bisa menjadi ilmu pengetahuan, yang pertama yaitu sumber pengetahuan dari rasio atau akal manusia yang pada akhirnya di kenal sebagai paham rasionalisme. Kedua yaitu sumber pengetahuan dari empiris atau pengalaman manusia yang akhirnya di kenal sebagai paham empirisme. Namun dalam Islam ada hal-hal yang tidak bisa di capai hanya dengan akal (rasional) dan pengalaman (empiris), Akan tetapi memerlukan adanya keimanan, dan keimanan itu sendiri berada di dalam hati manusia. Maka dari itu 
untuk mengetahui epistimologi dalam pendidikan Islam harus menggunakan rasio (akal), empiris (pengalaman) serta keimanan yang harus menjadi prioritas pertama sebagai umat Muslim. Sehingga umat Muslim dapat memperoleh pengetahuan yang luas serta sesuai dengan ajaran Islam.

Ketiga adalah aksiologi yang mengupas nilai-nilai pendidikan Islam. Kata aksiologi ini pun berasal dari dua kata dasar, yaitu aksios yang mempunyai arti nilai. Dan logos yang mempunyai arti ilmu/teori. Oleh karena itu aksiologi dapat di artikan sebagai salah satu cabang filsafat yang mempelajari tentang nilai dari suatu hal atau dapat di sederhanakan menjadi hasil tentang sesuatu yang telah di kaji sebelumnya. Sehingga jika di hubungkan dengan Islam maka nilai/hasil yang di maksud itu adalah nilai perilaku dari seseorang yang sudah mengetahui hakikat dari berbagai sumber pengetahuan, seperti tingkah laku seseorang, etika, ahlak dan seabagainya. pengertian pendidikan Islam, menurut Omar Muhammad al-Touny al-Syaebani, adalah usaha mengubah tingkah laku individu dalam kehidupan pribadi, masyarakat, dan lingkungan sekitarnya melalui proses kependidikan. Tentunya, tingkah laku yang perlu diubah adalah tingkah laku yang tidak segaris dengan ajaranajaran islam, kemudian diarahkan ke jalan yang islami. Usaha mengubah adalah pendidikan itu sendiri, sementara visi keislaman menjadi tujuan akhir dari pendidikan Islam

Setelah membahas landasan Pendidikan Islam, maka dalam hal ini pendidikan Islam dapat di jadikan upaya untuk mengarahkan dan memperbaiki tingkah laku manusia baik dalam tataran kehidupan pribadi maupun bermasyarakat melalui proses pendidikan. Tingkah laku yang di maksudkan disini adalah tingkah laku yang tidak sejalur dengan ajaran islam, yang kemudian melalui pendidikan islam di harapkan mampu mengarahkan manusia ke jalan yang islami.

Sejalan dengan itu, tidak hanya merubah tingkah laku melainkan juga untuk mewariskan ilmu pengetahuan yang berwawasan islami. Yang mana hal tersebut kemudian segala aspek usaha, tindakan, dan sebagainya yang di lakukan manusia di harapkan merujuk pada Al-qur'an dan Al-Hadits sebagai landasan umat muslim (Rizal, 2014). Selain itu pendidikan islam juga ber-upaya mengembangkan, mendorong serta mengajak peserta didik untuk hidup lebih dinamis dengan berdasarkan nilai-nilai yang tinggi dan kehidupan yang mulia. Dengan proses usaha tersebut, di harapkan akan terbentuk pribadi yang lebih sempurna, baik yang berkaitan dengan potensi akal, perasaan maupun perbuatannya. Sehingga dengan demikian pendidikan islam dapat dijadikan jalan untuk mengubah pola hidup dan pola pikir agar lebih terkendali dan tertata. Selain yang tersebut diatas, pendidikan islam juga mengupayakan perkembangan jasmani dan rohani manusia menggapai kepribadian yang yang utama yaitu menjadi insan kamil yang mulia dengan selalu ber-evaluasi diri sesuai dengan ajaran islam

Sehingga serangkaian usaha tersebut memang dipersiapkan untuk memperluas pengetahuan sesuai dengan nilai keislaman yang telah di selaraskan dengan fungsi manusia yang 
harus ber-amal sholeh di dunia sehingga dapat memetik hasilnya kelak di akhirat, karena pendidikan islam memang tidak hanya bersifat teoritis akan tetapi juga bersifat praktis. Maka pendidikan islam merupakan pendidikan iman sekaligus pendidikan amal.

Maka jelas filsafat pendidikan islam berupaya mencari kebenaran secara fundamental, supaya manusia dapat berfikir secara radikal dalam memecahkan problem yang terjadi dalam pendidikan islam, serta membentuk teori-teori baru ataupun pembaharuan dalam pelaksanaan pendidikan islam sesuai dengan tuntutan perkembangan zaman. Namun tetap tidak menyimpang dari sumber-sumber yang shohih yaitu Al-qur'an dan $\mathrm{Al}$-Hadits.

Pada dasarnya pendidikan islam ditinjau dari segi filosofis bertujuan merealisasikan nilai nilai keislaman. Nilai - nilai tersebut didasari oleh keimanan dan ketakwaan kepada Allah SWT. Para ahli berpendapat bahwa ada beberapa ciri dari definisi tujuan pendidikan islam yaitu : 1. Manusia diarahkan untuk menjadi pemimpin atau khalifah di muka bumi ini, tidak merusak alam melainkan menjaga alam sesuai perintah Allah SWT. 2. Tugas kekhalifahan manusia tidak lain dan tidak bukan semata - mata hanya untuk beribadah kepada Allah SWT. 3. Kekhalifahan dilaksanakan dengan baik dengan senantiasa berakhlaqul karimah. 4. Keberhasilan manusia dalam menjalankan tugas sebagai khalifah di dukung dengan adanya potensi keilmuan, akhlak, serta keterampilan yang dimiliki. 5. Mendapat kebahagiaan hidup dunia dan akhirat (Ibid, 5354). Dengan kata lain, pendidikan islam juga bertujuan mewujudkan anak didiknya menjadi insan kamil di muka bumi.
Pendidikan tidak pernah lepas kaitannya dengan filsafat. Karena dengan filsafatlah tujuan pendidikan dapat terwujud yaitu untuk mnecetak generasi baru dengan pemikiran - pemikiran yang kritik bersubstansi serta solutif. Selain itu juga membantu dunia pendidikan dalam melahirkan generasi - generasi yang berkemajuan. Di sisi lain filsafat pendidikan bekerja dalam hal melandasi pelaksanaan pendidikan, dengan kata lain fungsi filsafat pendidikan adalah sebagai norma pendidikan.

\section{Keterkaitan Santri Dengan Filsafat}

\section{Pendidikan Islam}

Dalam perspektif pendidikan islam, pendidikan sendiri mempunyai peran yang sangat penting dalam upaya mencetak manusia yang handal untuk menjawab segala tantangan yang datang akibat dari perubahan zaman. Yang mana dalam hal ini manusia merupakan gerakan human investment, yaitu gerakan yang mengupayakan pendidikan jangka panjang untuk mencetak sumber daya manusia yang handal. Oleh sebab itulah peran santri nantinya akan terjun di tengah-tengah masyarakat sebagai bentuk pengabdian kepada masyarakat, sekaligus untuk mengamalkan ilmu yang sudah di dapatkannya. Maka dari itu sudah sepantasnya santri di tuntut harus mempunyai sumber daya kemampuan yang mempuni untuk mengarahkan dan mendidik masyarakat ke jalan yang sesuai dengan ajaran islam. Dalam hal mendidik, santri nantinya akan berperan sebagai pendidik bagi peserta didik di suatu lembaga yang ia tempati untuk mengembangkan seluruh potensi peserta didiknya, baik dalam segi kognitif, afektif, atupun psikomotorik.

Hal ini tentu berkaitan dengan tujuan 
pendidikan Islam itu sendiri, yaitu menciptakan peserta didik atau masyarakat yang mampu menerapkan nilai-nilai ajaran islam dalam kehidupan sehari-hari, sehingga terwujud karakter-karakter islami dalam kehidupan. Dengan kata lain, tujuan pendidikan islam adalah mewujudkan nilai-nilai ajaran islam dalam perkembangan ke-pribadian peserta didik atau masyarakat melalui proses yang focus terhadap hasil akhir dan di amalkan hingga seterusnya. Hasil akhir itu sendiri yaitu membentuk manusia yang berkepribadian islami, bertaqwa kepada Allah SWT, ber-akhlakul karimah, sehat, berilmu, kreatif, mandiri dan menjadi warga negara yang demokratis serta bertanggung jawab, dan mampu menyeimbangkan antara kebutuhan dunia dan akhirat sehingga akhirnya terbentuk menjadi umat muslim yang paripurna berjiwa tawakkal secara total kepada Allah SW'T.

Dalam hal ini maka sangat jelas bahwasanya santri turun langsung ke masyarakat melalui pendidikan sebagai bentuk pengamalan dari hasil menimba ilmu di pesantren, sekaligus santri menimba ilmu untuk dirinya sendiri melalui pengalaman di masyarakat. Dimana yang nantinya dari hasil pengalaman tersebut santri dapat mengembangkan pengetahuan dan membantu memberi kontribusi yang besar dalam memajukan pendidikan dan mencerdaskan bangsa dengan menyeimbangkan ilmu agama dengan pengetahuan modern yang sekian lama semakin berkembang, atau yang sering di sebut dinamis.

Tabel keterkaitan santri dan filsafat Pendidikan Islam

\begin{tabular}{|c|c|}
\hline Santri & Filsafat Pendidikan Islam \\
\hline $\begin{array}{l}\text { Peserta didik dalam sebuah lembaga pendidikan } \\
\text { pesantren. }\end{array}$ & Studi filosofis tentang kependidikan dalam islam. \\
\hline Subyek dan obyek dalam pendidikan. & $\begin{array}{l}\text { Mempelajari tentang ontology, epistimologi, dan } \\
\text { aksiologi. }\end{array}$ \\
\hline $\begin{array}{l}\text { Seseorang yang sedang mencari jati dirinya untuk } \\
\text { dapat berinteraksi dengan lingkungan masyarakat. }\end{array}$ & $\begin{array}{l}\text { Upaya mencari kebenaran secara fundamental, } \\
\text { supaya manusia dapat berfikir secara radikal } \\
\text { dalam memecahkan problem yang terjadi dalam } \\
\text { pendidikan islam. }\end{array}$ \\
\hline $\begin{array}{l}\text { Seseorang yang didik dengan nilai - nilai moral } \\
\text { berlandaskan keislaman. }\end{array}$ & $\begin{array}{l}\text { Upaya untuk mengarahkan dan memperbaiki } \\
\text { tingkah laku manusia baik dalam tataran } \\
\text { kehidupan pribadi maupun bermasyarakat } \\
\text { melalui proses pendidikan. }\end{array}$ \\
\hline $\begin{array}{l}\text { Seseorang yang disiapkan mentalnya untuk siap } \\
\text { terjun kemasyarakat untuk berkontribusi secara } \\
\text { langsung mengajarkan serta mengamalkan yang } \\
\text { telah di dapat di pesantren. }\end{array}$ & $\begin{array}{l}\text { Upaya untuk mengarahkan dan memperbaiki } \\
\text { tingkah laku manusia baik dalam tataran } \\
\text { kehidupan pribadi maupun bermasyarakat } \\
\text { melalui proses pendidikan. }\end{array}$ \\
\hline $\begin{array}{l}\text { Seseorang yang dicetak sebagai generasi yang } \\
\text { memiliki pemikiran - pemikiran kritis dan solutif. }\end{array}$ & $\begin{array}{l}\text { Upaya bimbingan serta mencetak pesserta didik } \\
\text { untuk menjadi generasi yang berkemajuan. }\end{array}$ \\
\hline
\end{tabular}

Dari tabel diatas dapat di simpulkan bahwa keterkaitan santri dalam hal pendidikan islam yaitu melalui kontribusinya melalui pemikiran - pemikiran baru yang mereka dapat dari hasil mengemban pendidikan di pesantren. Melalui pemikiran yang baru dan kritis sesuai dengan nilai - nilai keislaman tersebut maka santri akan mudah membantu mengembangkan 
pengetahuan dalam hal memajukan pendidikan. Tidak hanya berhenti disitu, santri juga dapat memberikan contoh dari hasil pengalaman pengalaman empiris untuk diamalkan sebagai bentuk pengabdian dalam bidang pendidikan sesuai dengan nilai keislaman. Santri juga dapat berkontribusi dalam hal bimbingan tingkah laku yang kurang sesuai dengan ajaran islam yang tengah terjadi di tengah masyarakat saat ini. Nilai - nilai moral yang berlandaskan keislaman dapat diamalkan secara luas, selain mereka terima untuk dirinya sendiri nilai - nilai moral tersebut dapat mereka gunakan sebagai upaya mengarahkan tingkah laku manusia agar sesuai dengan ajaran islam dilingkungannya untuk diterapkan di dalam kehidupan sehari - hari. Sebagai generasi yang kritis dan berkemajuan diharap santri dapat selalu memberi solusi atau pemikiran yang dianggap masih menjadi problem di dalam dunia pendidikan islam. Sehingga pendidikan akan selalu berkembang sesuai dengan perkembangan zaman dengan berbagai tuntutan dan tantangan yang dihadapi.

Dari berbagai teori yang sudah dijelaskan, maka dapat di katakan pendidikan tidak bisa lepas dari kontribusi santri, terlebih lagi pendidikan islam. Yang mana santri itu sendiri di tuntut untuk mengamalkan dan menyebarkan ilmu nya kepada semua orang. Dan tentu hal-hal yang di sampaikan oleh santri tidak pernah lepas dari ajara islam, yang mana nantinya itu menjadi sebuah pendidikan bagi yang menerimanya, dan ketika santri memberi masukan kepada pendidikan sebagai bentuk perbaikan dari kekurangan masyarakat, maka disitulah letak kontribusi pemikiran filsafat dari santri tersebut, yang mana pemikiran-pemikiran itu di dapatkan dari hasil pengalaman pengabdiannya selama terjun ke masyarakat, yang kemungkinan besar pemikiran tersebut sudah di padukan dengan pengetahuanpengetahuan modern seperti pada saat ini, namun tetap berlandaskan pada nilai keislaman.

\section{KESIMPULAN}

Di era yang sudah modern identitas santri tidak bisa hanya di nilai dari orang yang belajar menuntut ilmu di dalam suatu pesantren, seperti perspektif orang-orang pada umumnya. Akan tetapi identitas santri adalah semua orang yang senantiasa selalu belajar menuntut ilmu dan (1) orang yang berusaha mendalami agama islam, (2) orang yang melakukan ibadah secara sungguh-sungguh, (3) orang yang sholeh/sholeha.

Filsafat pendidikan islam di kaji dari 3 aspek kajian, yaitu dari aspek ontology, aspek epistimologi, dan aspek aksiologi, sehingga dari ketiga aspek kajian ini mampu memberikan manfaat yang besar bagi calon pendidik. Ontology membahas tentang hakikat keberadaan pendidikan islam, epistimologi mebahahas sumber-sumber pendidikan islam, dan aksiologi menjelaskan tentang nolai-nilai pendidikan islam.

Santri merupakan salah satu pemberi kontribusi besar dalam filsafat pendidikan islam dengan berbagai pemikiran-pemikiran (akal/rasio) yang berasal dari ilmu agamanya, dari pengalaman dan juga dari tingkat keimanannya.

\section{DAFTAR PUSTAKA}

Chamidi, A. S. (2017). Membedah Identitas 
Santri. Agus Salim Chamidi Membedah Identitas Santri An-Nahdhah.

Ii, B. A. B. (2006). Filsafat Pendidikan Islam. Filsafat Pendidikan Islam.

Rizal, A. S. (2014). FILSAFAT PENDIDIKAN

ISLAM ISLAMI Oleh: Ahmad Syamsu Rizal A . PENDAHULUAN pendidikan baik pada tataran teoritis maupun praktis . Ia dapat merupakan aplikasi. Jurnal Pendidikan Agama Islam - Ta'lim.

Tolchah, M. (2015). Filsafat Pendidikan Islam: Konstruksi Tipologis dalam Pengembangan Kurikulum. TS AQAFAH.

https://doi.org/10.21111/tsaqafah.v11i 2.274

Hasyim, Muhammad. (2015). PEMIKIRAN K.H. YAHYA SYABRAWI DALAM PENDIDIKAN ISLAM DI PONDOK PESANTREN RAUDLATUL ULUM I GANJARAN GONDANGLEGI MALANG. $A n-N u b a$.

Rohinah.(2013). FILSAFAT PENDIDIKAN ISLAM; Studi Filosofis atas Tujuan dan Metode Pendidikan Islam. Jurnal Pendidikan Islam.

Arifin dan Suyoto dalam Imron Arifin, Kepimpinan Kyai Kasus Pondok Pesantren Tebu Ireng (Malang: Kalimasyahadah Press, 1993 ), 12. 